\title{
Implementation of The Democracy Culture for Fulfillment of The Social Economic Rights for The Correctional Clients at Correctional Center in Central Jakarta-Indonesia
}

\author{
Dina Setyani ${ }^{1}$, Fentiny Nugroho ${ }^{2}$ \\ \{dinasetyani89@gmail.com ${ }^{1}$, fentiny2015@gmail.com ${ }^{2}$ \} \\ ${ }^{1,2}$ Postgraduate Program in Social Welfare, Faculty of Social and Political Sciences, University of \\ Indonesia
}

\begin{abstract}
This study aims to describe the application of a democratic culture to fulfill the social economic rights of correctional clients. A democratic state guarantees and protects the human rights of every citizen, including socio-economic and cultural rights. Related to socio-economic rights, where every citizen has the right to work and get comfortable working conditions and free from discrimination. For correctional clients, getting a decent job is not easy because of their status as ex-prisoners. The distrust of former prisoners and the public who have not applied the democratic culture in their daily lives causes many correctional clients to receive discriminatory treatment from the public. This study wants to find answers to research questions: How to apply the democratic culture by the environment around the client in order to fulfill the social economic rights of correctional clients. The technique of collecting data is in-depth interviews, literature studies and documents and observations. The results of this study illustrate that correctional clients who have been independent and fulfilled their socio-economic rights get democratic attitudes from their surrounding environment. The democratic attitude obtained by the client is the attitude of the community around the client's place of residence who is willing to accept the client again after serving a prison sentence, family attitudes that always provide support for the independence of clients and community mentors who provide non-discriminatory guidance and always prioritize the best interests of the client. This study recommends that the government needs to make policies in the field of employment for ex-prisoners so that they can get decent jobs after being released from prison, so that their socio-economic rights are fulfilled and minimizing recidivism actions.
\end{abstract}

Keywords: Correctional clients, fulfillment of rights, democracy culture.

\section{Introduction}

Democracy is a government held based on the will and power of the people. Democracy is born from the demands of western society for equal rights and equal position before the law. This happened because in the days before the American and French declarations, each citizen was distinguished from his position both before the law and in the social order of society [1]. The uprightness of democracy as a system of social life and the political system is very dependent on the upholding of the supporting elements of democracy itself, where one of 
these elements is a state of law.The guarantee of human rights is one of the requirements for the concept of a legal state. This is in line with the emergence of a democratic state that recognizes equality before the law and human rights [1]. Therefore, democratic countries must provide guarantees and protection of the human rights of every citizen, both personal rights, political rights and social, economic and cultural rights.

Economic and social rights are related to the socio-economic aspects possessed by every human being, such as the right to get work and the elimination of all forms of discrimination in life in society. Every citizen has the right to work and get comfortable working conditions and is free from discrimination and degrading treatment. However, this is not easy to realize because until now there is still found discriminatory treatment for marginalized groups in finding work, one of which is for correctional clients. Status as a former prisoner often prevents correctional clients from getting decent jobs. Public distrust of ex-prisoners and the fear of ex-prisoners will have a negative impact on business activities causing many of them not to be employed in the formal sector [2]. This is one example that guarantees and protection of human rights in a democratic country have not been fulfilled properly. The community as part of citizens also has not fully implemented the culture of democracy in everyday life, so there are still many discriminatory behaviors found by the community towards correctional clients. A democratic culture is a view of life that is reflected in the attitude that is able to launch a democracy in a better direction. According to Wilujeng, the success or failure of democracy is not merely marked by freedom for citizens, but also an increase in citizens' understanding of rights and obligations, tolerance and respect for diversity. Therefore, a democratic culture needs to be understood and built by every citizen so that the value of social justice for the people's prosperity which is the goal of democracy can be fulfilled.

In order to fulfill the social economic rights of correctional clients, a democratic culture needs to be developed and implemented based on the value of humanity, namely an increase in respect for humanity. The application of a democratic culture to fulfill the client's socioeconomic rights can be carried out by the client's family, the community and the government in this case the Correctional Institution as an agency that is obliged to guide the client during parole. In international journals and national journals, many have discussed the issue of human rights violations received by ex-prisoners after being released, such as limited employment, negative status in the community. However, no research has been conducted on the application of democratic culture by the environment around clients in an effort to fulfill the social economic rights of correctional clients. Therefore, this study wants to raise the application of democratic culture by the environment around the client in order to fulfill the social economic rights of correctional clients.

This research was conducted with a qualitative approach with descriptive research types. Informants in this study were adult clients who succeeded in developing self-reliance. The clients who have succeeded and were able to become informants in this study were 6 people, with details 3 people had attended skills training in Correctional Center and 3 other people had never participated in skills training. Other informants are family, community mentors and community around the client's residence. This research took place at the Correctional Center in Central Jakarta because it was one of the pilot groups in correcting client counseling in the Jakarta area. Data collection techniques are done by studying literature and documents, indepth interviews and observations. The data analysis technique uses the techniques of Huberman and Miles in Denzin and Lincoln [3] namely data collection, data reduction, data presentation and verification or conclusions. 


\section{Result and discussion}

The results showed that correctional clients who have decent jobs and succeeded in developing their self-reliance gained democratic attitudes from the surrounding environment. Democratic attitudes were shown by the family, society and government to be stated to community mentors at the Correctional Center.

\subsection{Family}

The family is the smallest community environment, where a child as a family member learns and practices to understand and appreciate values, norms and behavior patterns through early education. Parenting in a family that is closely related to the norms of forming patterns of communication in the family. Communication that is well established between family members is the initial foundation for the formation of a democratic life in the family and is able to create a harmonious family. In order to realize the ideals of democratic life, every family member must be able to understand the rights and responsibilities in a family. Likewise, every family member and community member must obtain and provide various forms of support and protection, especially those that are moral in nature.

The results of the study show that clients who have succeeded in developing self-reliance and fulfilling their socio-economic rights have gained a lot of moral support from their families. Support is provided to foster confidence and develop the client's potential to get a job. Clients who have successfully developed their self-reliance generally have good selfconfidence and have a strong desire to change for the better. This desire arises because of a deep sense of regret towards the family and a sense of responsibility towards oneself and family. They have had the awareness and deterrence of criminal acts that have been committed, so that the desire arises from within to be able to change for the better and a sense of abstinence from all situations and conditions that can hinder their self-reliance.

The existence of support provided by the family to the client shows that the communication that exists between family members goes well, where each family member can reveal every problem faced and solve the problem together with other family members. This indicates that in the family a democratic culture has been built, so that it can be beneficial for clients to develop their independence. According to Kuswanti, the success factor for creating harmony in the family is communication between family members supported by a democratic system, so that every problem can be solved together and all family members feel that they have balanced rights and obligations according to their role in the family [4].

\subsection{Community}

The purpose of the correctional system is to re-populate prisoners so that they become good and useful citizens, which in essence is a process that focuses not only on individual convicts, but also on the unity of relations between the convicted person and the community. To carry out the correctional system, community participation is needed in terms of coaching by being willing to accept returnees after undergoing the sentence.

The results of the study show that correctional clients who have succeeded in developing their independence can be well received by the community around their residence. Community acceptance of correctional clients is indicated by not giving negative stigma or ridicule to clients. The attitude of the community that does not discriminate against the client is one form of fulfilling the client's social rights, making it easier for the client to adapt again to the environment in which he lives and develop economic independence. In addition, the attitude of the community also indicates that a culture of democracy has been built into the 
community. Handitya revealed that one application of a democratic culture in the community is manifested in the form of willingness to live together with community members without discrimination [5].

\subsection{Government (Community Mentors)}

The government in this study was represented by the Correctional Center whose duty was to carry out guidance to clients. Implementation of guidance is carried out by correctional officers named Community Mentors. Community mentors in carrying out guidance to clients must fulfill several guiding principles, namely: non-discrimination, the best interests of the client, respect for the client, acceptance, communication, individualization, participation, confidentiality and self-awareness of the community mentors [6].

The results of the study indicate that the client receives guidance from the community mentors well. Community mentors always provide opportunities for clients to tell their problems and then try to solve client problems together. In carrying out guidance, community mentors are non-discriminatory or without differentiating and accepting clients in a friendly and professional manner. In addition, community mentors always provide information related to the implementation of job training at the Correctional Center, so that clients who have not worked get the same opportunity to attend training. This indicates that the government represented by the Correctional Center has tried to fulfill the rights of clients by carrying out the task of mentoring with a culture of fair democracy, so that correctional clients are fulfilled their social and economic rights. Correctional client economic rights that have been fulfilled by the government are equal opportunities to take part in job skills training held by the Correctional Center, while fulfilled social rights are clients get guidance without discrimination. This is in accordance with the concept of a democratic state, where the state is obliged to issue all laws and other legal instruments that guarantee the fulfillment of human rights for all citizens, the State is not permitted to interfere or obstruct any efforts made by the community in fulfilling their human rights [7].

\section{Acknowledgements}

We would like to thank the University of Indonesia's Directorate of Research and Community Service for supporting this research. We are also thank the Correctional Center in Central Jakarta of the Ministry of Law and Human Rights of the Republic of Indonesia for giving us the opportunity to conduct research. In addition, we also thank the informants, namely correctional clients, the surrounding community and community mentors who have been willing to take the time to provide information related to the research that we do.

\section{References}

[1] B. B. Irawan, "Perkembangan demokrasi di Negara Indonesia," Huk. dan Din. Masy., vol. 5, no. 1, pp. 54-64, 2007.

[2] Z. Akhyar, H. Matnuh, and M. Najibbudin, "Persepsi masyarakat terhadap mantan narapidana di Desa Benua Jingah Kecamatan Barabai Kabupaten Hulu Sungai Tengah,” J. Pendidik. Kewarganegaraan, vol. 4, pp. 545-557, 2014.

[3] N. K. Denzin and Y. S. Lincoln, Handbook of Qualitative Research (Dariyanto, Badrus Samsul Fata, Abi, John Rinaldi, penerjemah). Yogyakarta: Penerbit Pustaka Pelajar, 2009.

[4] A. Kuswanti, "Mengembangkan pola komunikasi antarpribadi dalam menciptakan keharmonisan keluarga antara orangtua dan anak," J. Ikon, pp. 282-298, 2015.

[5] B. Handitya, "Merawat sikap dan perilaku hidup demokratis melalui pendidikan politik," in Seminar Nasional Hukum Universitas Negeri Semarang, 2018, pp. 629-650.

[6] Kementerian Hukum dan HAM RI, Modul Pembimbing Kemasyarakatan. Jakarta: Penerbit 
Direktorat Jenderal Pemasyarakatan, 2012.

[7] E. Rosana, "Negara demokrasi dan hak asasi manusia," J. TAPIs, vol. 12, no. 1, pp. 37-53, 2016. 